\title{
Supply of crab larvae to an estuary in the eastern Atlantic upwelling system exhibits predictable and haphazard variation at different temporal scales
}

\author{
Carla P. Domingues ${ }^{1, *}$, Maria João Almeida ${ }^{1}$, Jesus Dubert ${ }^{2}$, Rita Nolasco ${ }^{2}$, \\ Nuno Cordeiro ${ }^{2}$, Silke Waap ${ }^{3}$, Ana Sequeira ${ }^{1}$, Sofia Tavares ${ }^{1}$, Henrique Queiroga ${ }^{1}$ \\ ${ }^{1}$ CESAM \& Departamento de Biologia, Universidade de Aveiro, Campus Universitário de Santiago, 3810-193 Aveiro, \\ Portugal \\ ${ }^{2}$ CESAM \& Departamento de Física, Universidade de Aveiro, Campus Universitário de Santiago, 3810-193 Aveiro, Portugal \\ ${ }^{3}$ Faculdade de Ciências do Mar e do Ambiente, Universidade do Algarve, Campus de Gambelas, 8005-196 Faro, Portugal
}

\begin{abstract}
We measured variability in daily supply levels of shore crab megalopae in an estuary on the northwest Portuguese coast, Ria de Aveiro, located in the eastern Atlantic upwelling system. The 5 yr study covered the shore crab larval season (generally February to July) in 2002 and from 2006 to 2009. We addressed the possible effects of wind- and tide-driven circulation, number of flood hours during darkness, and chlorophyll a concentration in coastal waters on larval supply variation. Megalopae supply measured over the years was an episodic phenomenon, and observations showed some predictable and haphazard patterns. In some episodes, supply was highest around spring tides and was enhanced by southerly winds, as predicted, although not all episodes fitted this pattern. The relationships between supply levels and number of flood hours during darkness or chlorophyll a concentration were ambiguous throughout the time series, although in some years increased levels of supply were positively correlated with number of flood hours during the night. The analysis of multiple years conducted in this study showed that shore crab megalopae supply patterns to Ria de Aveiro are more variable than previously assumed, suggesting the participation of several delivery mechanisms that vary within and among years. However, a proportion of supply variation exists that cannot be explained by the mechanisms we propose.
\end{abstract}

KEY WORDS: Larval supply $\cdot$ Carcinus maenas $\cdot$ Wind $\cdot$ Tides $\cdot$ Flood hours $\cdot$ Chlorophyll a

\section{INTRODUCTION}

Transport by coastal currents has been shown to affect larval supply, settlement, recruitment, population genetic structure, species ranges and the spread of invasive species of coastal marine invertebrates and fishes with complex life cycles (Gaines \& Roughgarden 1985, Farrell et al. 1991, Pineda 1991, Alexander \& Roughgarden 1996, Byers \& Pringle 2006, Pringle \& Wares 2007, Cowen \& Sponaugle 2009). Diverse physical forcing features occurring in nearshore and coastal environments cause variation in circulation patterns that may result in temporal variation of larval supply to coastal marine populations. The causes of variation in larval supply are diverse, and assessing the relative contribution of multiple mechanisms is extremely difficult; contrasting results have been reported across time, space and taxa (e.g. Roughgarden et al. 1988, Poulin et al. 2002, Miller \& Shanks 2004, Shanks \& Brink 2005, Mace \& Morgan 2006).

Wind circulation patterns drive upwelling and downwelling events; this mechanism has been proposed to affect the timing and distribution of larval supply and settlement. Populations from upwelling systems along the western margin of continents are often viewed as recruitment-limited (Connolly et al. 2001). Traditionally, it has been assumed that during upwelling-favourable wind periods, planktonic larvae 
dwelling in surface waters are transported offshore, and that the opposite occurs during the relaxation of upwelling-favourable winds or during downwellingfavourable winds (e.g. Roughgarden et al. 1988, Farrell et al. 1991, Wing et al. 1995, Connolly et al. 2001, Almeida \& Queiroga 2003, Queiroga et al. 2006). However, while some larvae behave as passive particles that may follow shifting ocean currents, others are capable swimmers that can actually control their vertical distribution in the water column and subsequently their cross-shelf transport (Queiroga \& Blanton 2004, Queiroga et al. 2007). These larvae can remain in nearshore waters and thus are able to be transported shoreward independently of upwelling or downwelling conditions (Poulin et al. 2002, Miller \& Shanks 2004, Shanks \& Brink 2005, Morgan \& Fisher 2010). The complex interaction between environmental wind forcing and larval behaviour contributes to larval supply variation to coastal habitats, but other phenomena such as tide-driven circulation, number of flood hours during darkness and chlorophyll concentration may act together to produce high variability in larval supply levels.

Tide- and lunar cycle-driven patterns of megalopae supply occurring around spring tides have been described for some estuarine and mangrove populations of brachyuran crabs using selective tidal stream transport (STST) to travel up estuaries (van Montfrans et al. 1990, Moser \& Macintosh 2001, Paula et al. 2001, Miller \& Shanks 2004, Queiroga et al. 2006). These patterns have been related to larval response to increased hydrostatic pressure, salinity and turbulence during spring tides (e.g. Queiroga et al. 2006) or to a combination of onshore transport by internal waves and diel vertical migration (Miller \& Shanks 2004). When returning to estuaries, late stage decapod larvae use STST to travel upstream, occupying a higher position in the water column during the night and a lower position close to the bottom during daytime, triggered by chemical cues present in the water and presumably to avoid visual predators (Queiroga 1998). Therefore, the number of flood hours during darkness can also influence supply intensity.

Phytoplankton is a direct or indirect source of food for most marine animals and may constitute an important component of the natural diet of decapod larvae (Factor \& Dexter 1993, Meyer-Harms \& Harms 1993), especially when nutrition is limited in the field (Harms et al. 1994). Chlorophyll a ( $\mathrm{chl}$ a) concentrations are an indicator of phytoplankton abundance and biomass in estuarine, coastal and oceanic waters (Cullen 1982) and therefore may be correlated with the abundance of larvae. Larvae in good nutritional condition may be more capable of surviving and successfully recruiting inside estuaries. Temporal and spatial variation in the concentrations of chl $a$ in surface waters may be related to nutrient concentrations, wind-driven turbulence intensity, hydrodynamics and turbidity (Franks 1992).

Addressing the mechanisms driving the variation in larval supply and settlement is challenging and requires data collection over long time series, including interannual comparisons, in order to describe the relevant processes with sufficient detail. Only a few studies have collected these types of data (e.g. Goodrich et al. 1989, van Montfrans et al. 1990, 1995, Jones \& Epifanio 1995, Wing et al. 2003, Giménez \& Dick 2007, Roegner et al. 2007).

In the present work, we examined the potential influence of some mechanisms and features on observed patterns of larval supply (late stage larvae: megalopae) to an estuary in the eastern Atlantic upwelling system for a coastal marine invertebrate, Carcinus maenas (Decapoda, Portunidae). We combined detailed oceanographic data with daily larval supply information obtained during the reproductive season in 5 different years. C. maenas has a complex life cycle with 4 pelagic zoeae and a megalopa and is widely distributed on both hard and soft intertidal and shallow subtidal habitats of coasts and estuaries along its native European range.

We investigated the effect of wind- and tide-driven circulation, number of flood hours during darkness and chl a concentration on larval supply. We collected data daily over several months in the reproductive season of 5 years, and used a multiple regression approach where standard errors were recalculated to account for the effect of autocorrelation of the variables. Specifically, we tested the hypotheses that (1) larval supply should increase after downwelling-favourable, or relaxation of upwelling-favourable, winds, (2) larval abundance should vary with the fortnightly tidal cycle, (3) larval supply should increase with increased number of flood tide hours occurring at night, and (4) larval abundance should increase after high levels of chl a concentration in the coastal ocean.

\section{MATERIALS AND METHODS}

Field sampling and environmental data. Research was conducted at Canal de Mira located within the Ria de Aveiro estuary in northwestern Portugal $\left(40^{\circ} 37^{\prime} 17^{\prime \prime} \mathrm{N}, 8^{\circ} 44^{\prime} 56^{\prime \prime} \mathrm{W}\right.$; Fig. 1). Circulation in the Ria de Aveiro is dominated by tides, which are semidiurnal with an average range of $2.1 \mathrm{~m}$. Field sampling was conducted from March to June of 2006 and 2007 and from February to July of 2008 and 2009, covering the peak times of megalopae supply for Carcinus maenas on the northwest Portuguese coast. Addition- 
ally, in order to increase the amount of data for interannual comparison, we used information from a previous study of Queiroga et al. (2006) in which field sampling took place from April to July of 2002.

Larval supply was measured with the use of 2 passive plankton nets, as described by Queiroga et al. (2006). These nets were designed to be continuously

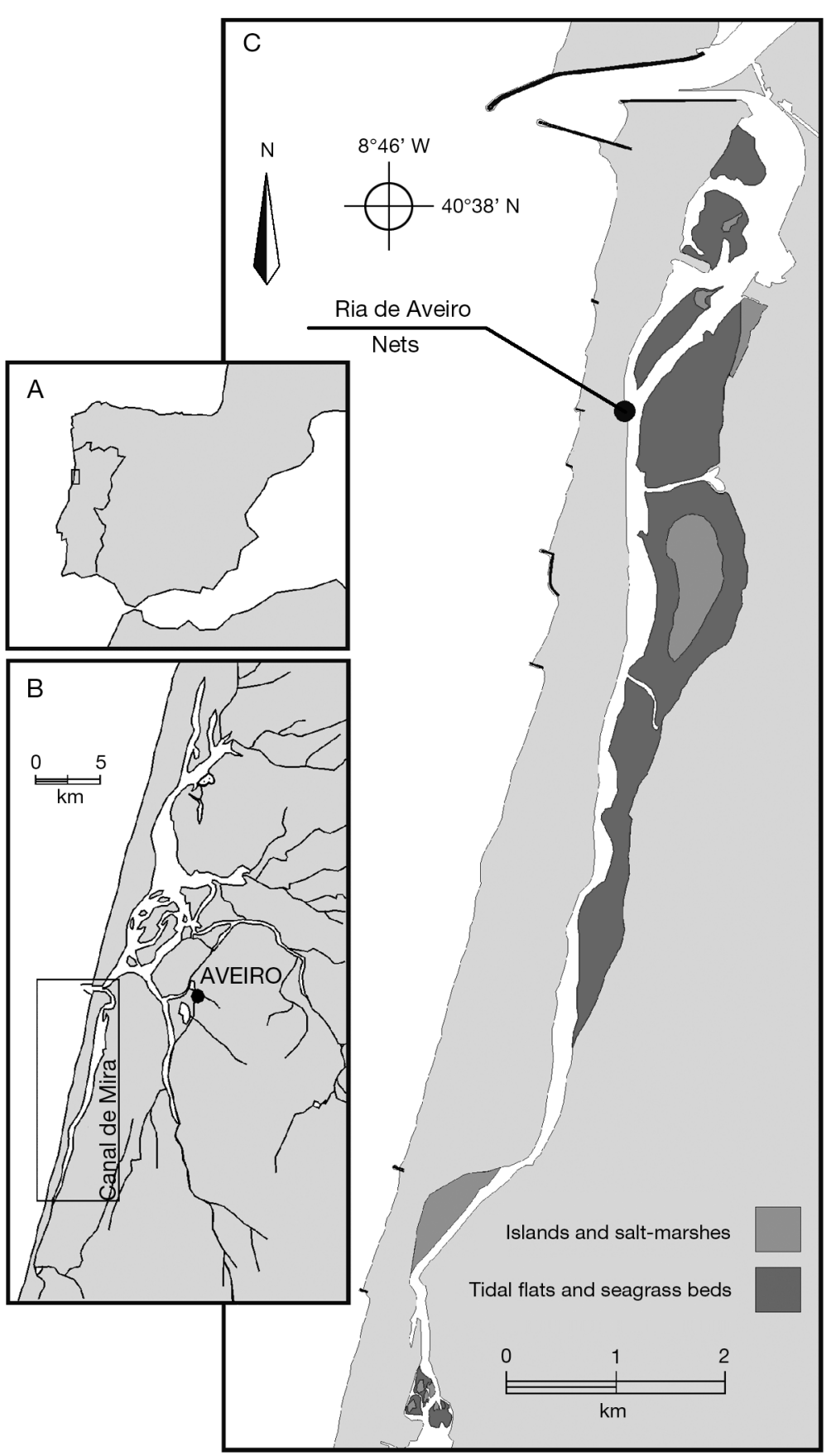

Fig. 1. Sampling location for Carcinus maenas megalopal supply. (A) Iberian Peninsula, (B) Ria de Aveiro, NW Portugal and (C) Sampling location submersed, but to sample megalopae only during the flood tide, with a baffle inside the nets to prevent the loss of material during ebb tide. One net was deployed at the water surface and the other was deployed above the bottom, and both nets were recovered each morning for enumeration of megalopae. Wind velocity for the region was obtained from the widely used National Centers for Environmental Prediction (NCEP) Reanalysis data project provided by the NOAA/OAR/ESRL PSD, Boulder, Colorado, USA, from their web site at www.esrl.noaa.gov/psd/ (Kalnay et al. 1996). Both components of wind, $u$ (positive for westerly winds) and $v$ (positive for southerly winds), were extracted for the point $40^{\circ} 53^{\prime} \mathrm{N}, 9^{\circ} 22^{\prime} \mathrm{W}$, every $6 \mathrm{~h}$. From these data, we calculated the wind stresses (c.f. Queiroga et al. 2006) for both north-south (along-shore) and east-west (cross-shore) components, which were then averaged over a $24 \mathrm{~h}$ period. Sea-level data were obtained from the Aveiro tide gauge, which is located at the inlet channel of the Ria de Aveiro. Daily tidal range was recorded as the change in tidal height between the averages of the 2 daily maxima and the 2 daily minima water levels. Daily subtidal sea level (SSL) was computed by running a $13 \mathrm{~h}$ moving average over the hourly sea level values in order to remove the tidal signal, followed by the calculation of the average of the filtered values for each day. Daily sea surface temperature (SST) data were obtained from a weather station of the Portuguese Instituto de Meteorologia located at Leixões, $60 \mathrm{~km}$ north of the Ria de Aveiro. Tidal elevation series were extracted and analysed from tides predicted for the western Iberian region (Marta-Almeida \& Dubert 2006). These data, together with the sunrise and sunset times published by the Observatório Astronómico de Lisboa for the period in analysis, allowed us to calculate both the total daily number of flood hours and the number of flood hours during darkness. Series of chl a concentration were extracted from satellite-observed chl $a$ in the sea water $\left(\mathrm{mg} \mathrm{m}^{-3}\right.$ ) obtained by optimised interpolation of the MODIS, SeaWiFS and MERIS OC5 chl a fields, andsupplied by CERSAT/IFREMER, France, through their ftp server (ftp://ftp.ifremer.fr/ifremer/cersat/ products/gridded/ocean-color/atlantic/EURL4-CHL-ATL-v01). Based on the daily mean distribution of the chl a within a pixel of 
$0.015^{\circ}$ (nearly $1.65 \mathrm{~km}$ latitude $\times 1.28 \mathrm{~km}$ longitude), a time series of spatially averaged chl a was calculated for a rectangle extending $100 \mathrm{~km}$ to the north and south of the Aveiro inlet and $40 \mathrm{~km}$ offshore (approximately the shelf break).

Statistical analysis. In order to describe the mechanisms that control larval supply to coastal habitats, it is necessary to identify the time lag between environmental forcing and the subsequent response of the coastal ocean and of larval supply. In the present study, this was done using cross-correlation (Chatfield 1996) and least squares multiple regression (Sokal \& Rohlf 1995), where the forcing variable preceded the response variable, indicated throughout this paper by negative numbers. Effects of wind on SSL, SST, chl a and supply were tested for lags $\geq-5 \mathrm{~d}$ and $\leq 0 \mathrm{~d}$, because it is difficult to meaningfully interpret situations where winds or tides precede hydrographical variables or supply by $\leq-5 \mathrm{~d}$. The effect of tides on megalopal supply was investigated down to lags of $-15 d$, in order to detect possible cases of fortnightly periods only evident in shorter segments of the data series. As the expected effect of chl a on supply is through changes in larval mortality associated with food conditions, which would take longer to act than the effects of other variables on larval advection, we tested this with lags down to $-14 \mathrm{~d}$. In the case of night flood hours, the effect on supply was tested down to lags of $-2 \mathrm{~d}$. This is justified on the basis that maximum values of night flood hours on the Portuguese coast coincide either with the lowest (in autumn and winter) or highest (in spring and summer) amplitude tides within the semilunar cycle (Queiroga \& Blanton 2004), and because megalopal supply was found to be dependent on tidal range at lags $\geq-2 \mathrm{~d}$ (see 'Results').

All cross-correlations were computed over the differenced series for each variable using a time lag of $-1 \mathrm{~d}$ to remove the autocorrelation that was present in all data series (Chatfield 1996) and which could increase the probability of Type I errors. The auto-correlation present in the time series at the time lag of $-1 d$, reflecting the influence of megalopal supply of any one day on that of the next day, violates the assumption of independence required by least squares regression and would also result in increased probability of Type I errors. As a result, the residuals produced by the adjustment of the multiple regression models presented an autocorrelation structure that followed a first order autoregressive process. Therefore, in order to remove dependence of the data we applied the transformation $x_{d}-\Phi x_{d-1}$ to all the independent variates $x$, where $\Phi$ represents the autoregressive coefficient at that time lag (d) (Alpuim \& El-Shaarawi 2008), similarly to the methodology applied by Queiroga et al. (2006).
According to upwelling theory, which predicts a drop in the SSL and a decrease in SST at the coast during an increase in upwelling-favourable winds (equatorward wind stress), if the coastal ocean is responding to wind-driven circulation, then SSL and SST should be correlated with the alongshore component of wind stress. We used cross-correlations to test this hypothesis and demonstrated that the upwelling-downwelling mechanism was operating during the sampling periods.

The relationship between environmental variables and daily supply of megalopae was analysed using cross-correlation and a least squares multiple regression model, applied separately to the total data series obtained in each year. In an exploratory approach to detect relationships between pairs of variables and time lags of effects, we used cross-correlation analysis in which megalopal abundance was separately lagged against tidal range, number of flood hours during darkness and chl a concentration. We then used a least squares multiple regression model of daily supply against wind and tidal forcing, number of flood hours during darkness and chl a concentration at different time lags as a predictive approach similar to that described by Queiroga et al. (2006). We applied multiple regression separately for each year, in a stepwise forward fashion starting with a set of sine and cosine functions that account for the semilunar cycle of tidal range and with along-shore wind stress, which are the main factors previously known to control supply of megalopae to estuaries on the Portuguese west coast (Queiroga et al. 2006). We decided to model tidal range with sine and cosine functions (with periods of 14 or $15 \mathrm{~d}$, depending on which produced a better adjustment) using the property that any periodic function with a period equal to an entire number can be described by a linear combination of sine and cosine functions with periods equal to submultiples of the period of the main cycle (Wei 1990). This option was chosen instead of using observed tidal range because (1) cross-correlation indicated that delays between megalopal supply and tidal range were short $(\geq-2 \mathrm{~d}$ and $\leq 0 \mathrm{~d})$, (2) the automatic phase adjustment of the sine and cosine functions eliminates the need to test different lags and (3) the observed tidal range produced inferior adjustments, probably due to the range inequality in consecutive fortnightly cycles. Whenever there was a significant effect of wind or tidal range on megalopal supply, we introduced the other variables: chl a concentration and number of flood hours during darkness. SSL and SST were not used in the regression model because they ultimately depend on the wind variable and co-vary linearly with it. When running the regression model, variables that were not significant were discarded. Due to the existence of the autocorre- 
lation structure in the residuals, the use of the determination coefficient $r^{2}$ to evaluate the overall fit of the regression model is not appropriate. Instead we used a modification of this statistic, $r^{* 2}$, where the sum of squares of residuals was replaced by the sum of squares of the white noise sequence produced by the adjustment of an autoregressive process to the residuals (Queiroga et al. 2006). This sum of squares is a more realistic measure of the variability due to unexplained error because it accounts for the day to day dependence of the observations. From all the fitted models we retained the one with the highest fit, according to the respective $r^{* 2}$.

Along the west Iberian Peninsula, the number of hours of flood tide that take place during darkness is maximised on spring tides during spring and summer, whereas during autumn and winter it is maximised during neap tides (Queiroga \& Blanton 2004). Available evidence shows that supply of crab megalopae to estuaries typically occurs during night flood tides (Little \& Epifanio 1991, Olmi 1994, Queiroga 1998), but that tidal range also influences supply of crab and other invertebrate larvae to coastal habitats, either through internal wave transport (Shanks 1983, 1988, Pineda 1991) or through short-term behavioural responses to changes in hydrostatic pressure (Tankersley et al. 1995). In an attempt to separate the influence of night flood from tidal range, we split the time series obtained in each year at Year Day 90, which marks the transition between the periods when maximisation of nocturnal floods co-occurs with neap or spring tides, and applied cross-correlation and multiple regression on the time series collected before and after Day 90 . Hereafter, we refer to these periods as the complete, before Day 90 and after Day 90 data sets.

\section{RESULTS}

Typical upwelling-favourable winds (northwesterly) dominated during the sampling period of all years, particularly in 2002, followed by 2009, 2008, 2007 and 2006 as shown in Figs. $2 \mathrm{~B}$ to $6 \mathrm{~B}$ by wind stresses with a negative along-shore component and a positive cross-shore component. Downwelling-favourable winds (southwesterly), evidenced by wind stresses with positive alongand cross-shore components, were less frequent, especially in 2002 and 2009 (although events of 6 to 7 d were observed during the study period in these years) (Figs. 2B \& 6B). Southwesterly wind episodes were more frequent in the remaining 3 years when strong and extended events occurred at the beginning of spring 2006, from Days 77 to 91 (Fig. 3B), just prior to the beginning of summer 2007, from Days 158 to 170 (Fig. 4B), and during spring 2008, from Days 107 to 114 (Fig. 5B).

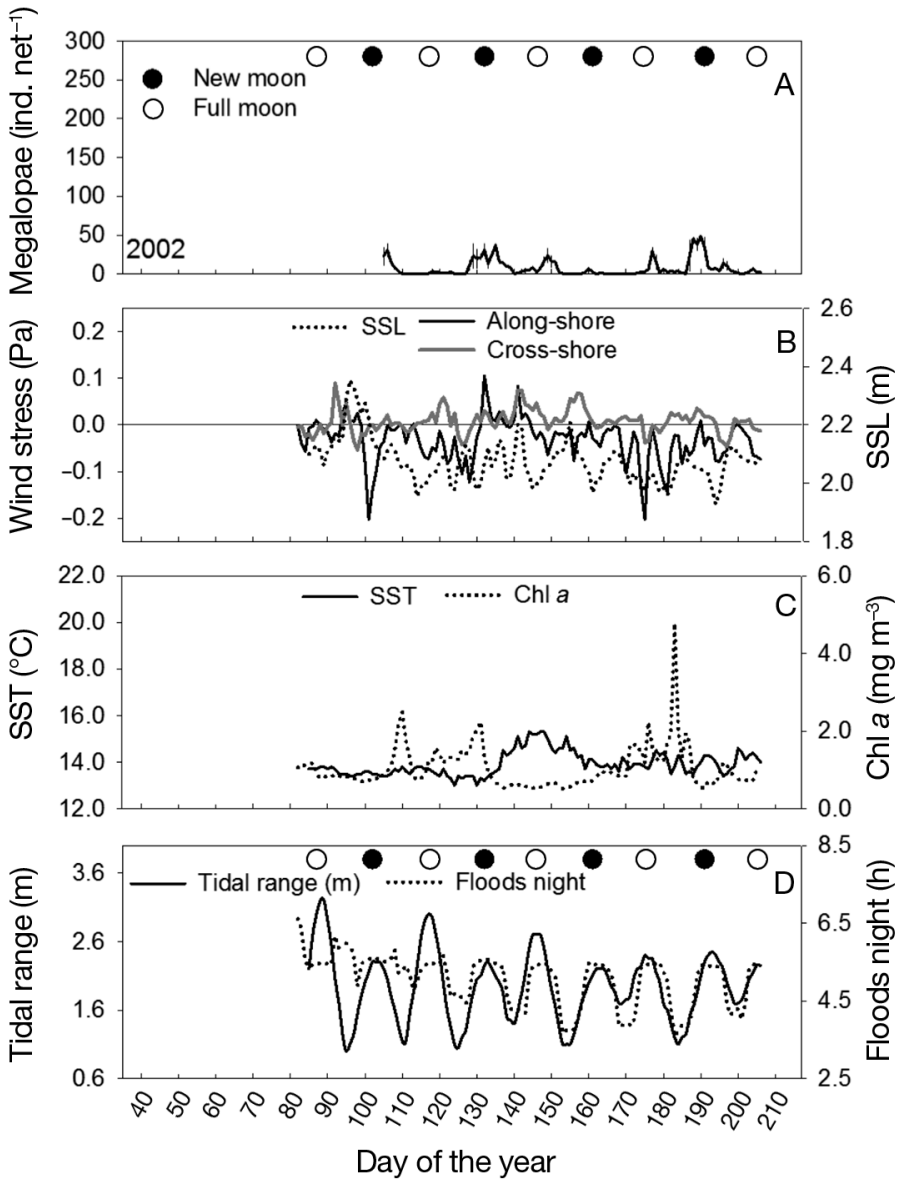

Fig. 2. Time series at Ria de Aveiro for year 2002. Daily averages of (A) Carcinus maenas. megalopal supply, (B) alongshore and cross-shore wind stress and subtidal sea level (SSL), (C) sea surface temperature (SST) and chlorophyll a (chl a) concentration, (D) tidal range and flood hours at night

SST values fluctuated from 12 to $19-20^{\circ} \mathrm{C}$ (Figs. 2C to $6 \mathrm{C}$ ) and, with the exception of 2006, SST was always associated with wind stress at lags of -1 to $-4 \mathrm{~d}$, as confirmed by maximum significant positive cross-correlations between alongshore wind stress and SST. Slightly stronger correlations were found for the split data series obtained both before and after Day 90 (Table 1). The response of the ocean to wind stress in terms of SSL occurred for time lags of 0 and $-1 \mathrm{~d}$, as evidenced by maximum significant positive cross correlations between alongshore wind stress and SSL. For the complete data series and the data obtained before Day 90, significant relationships were observed for all years, but not for the period after Day 90 (Table 1).

Abundance of megalopae recorded in the nets varied by a factor of 4 among years, from a maximum average of 12 individuals (ind.) net ${ }^{-1} \mathrm{~d}^{-1}$ in 2006 and a minimum average of 3 ind. net ${ }^{-1} \mathrm{~d}^{-1}$ in 2009 (Figs. 2A to $6 \mathrm{~A}$ ). If larval abundance varied with the fortnightly tidal cycle, number of flood tide hours during darkness 
Table 1. Time lags (d) and cross-correlations ( $r$ in parentheses) between the alongshore component of wind stress (WS) and sea surface temperature (SST) and subtidal sea level (SSL), applied to the complete data series (All) and to the data obtained before (B90) or after (A90) Day 90. The length of each of the time series is also given. Reported values refer to maximum significant $(p<0.05)$ cross-correlations in each case; nd: no data; ns: not significant

\begin{tabular}{|ccccc|}
\hline \multirow{2}{*}{ Year } & & \multirow{2}{*}{$\begin{array}{c}\text { Length of } \\
\text { time series }\end{array}$} & SST & SSL \\
\hline \multirow{2}{*}{2002} & & & & \\
& All & 102 & nd & nd \\
& B90 & nd & nd & nd \\
& A90 & nd & $-1(0.368)$ & $0(0.257)$ \\
2006 & All & 115 & ns & $0(0.516)$ \\
& B90 & 24 & ns & $0(0.591)$ \\
& A90 & 91 & ns & $0(0.403)$ \\
2007 & All & 112 & $-1(0.209)$ & $0(0.232)$ \\
& B90 & 20 & ns & $-1(0.442)$ \\
& A90 & 92 & $-1(0.338)$ & ns \\
2008 & All & 163 & $-1(0.247)$ & $0(0.245)$ \\
& B90 & 40 & $-4(0.366)$ & $0(0.500)$ \\
& A90 & 123 & $-1(0.254)$ & ns \\
2009 & All & 155 & $-1(0.171)$ & $0(0.488)$ \\
& B90 & 32 & $0(0.496)$ & $-1(0.465)$ \\
& A90 & 123 & $-3(0.204)$ & $0(0.552)$ \\
& & & & \\
\hline
\end{tabular}

and levels of chl a concentration, we should find significant cross-correlations between megalopae catches and the cited variables. Significant correlations between abundance in the plankton nets and tidal range were never observed when the complete time series were analysed, but were present in the split data sets in 2002 and 2006 after Day 90, and in 2007 before Day 90 , with maximum values at time lags of -2 or $-15 \mathrm{~d}$ (Table 2). Megalopal abundance was positively correlated with flood hours during darkness in 2002 and 2006, at time lags ranging from -2 to $+2 \mathrm{~d}$. In 2002, significant associations were only found after Day 90, while in 2006, all periods analysed showed significant values. In 2007, 2008 and 2009, number of flood hours during darkness was not associated with larval supply at any lag (Table 2). Maximum values of chl a were obtained at the end of June in 2002 and 2006 and during February and March in 2009 (Figs. 2C to 6C). In 2007 and 2008, chl a levels were generally slightly lower compared with the other years (Figs. 4C \& 5C). After analysis of the entire series, we only found a significant positive correlation between larval abundance and chl a concentration at a lag of $-14 \mathrm{~d}$ in 2007 (Table 2). Before Day 90, significant correlations were found in all years at time lags ranging from 0 to $-12 \mathrm{~d}$, and after Day 90, cross-correlograms between megalopal supply and chl a concentration indicated delays ranging from -5 to $-14 \mathrm{~d}$, except in 2006 when the correlation was not significant (Table 2).
Results of the application of the regression model are reported in Table 3, which shows the best combination of variables to explain supply of Carcinus maenas megalopae in each year and period (complete, before Day 90 and after Day 90 data sets). Application of the multiple regression models in general improved the ability to detect significant associations of megalopal supply with forcing variables relative to the use of cross-correlations. This is apparent from the larger number of cases where a significant effect of individual variables was detected (compare Table 2 with Table 3 ) and results from simultaneously accounting for the effect on supply of the remaining variables in the models. Significant effects of tidal range were detected in all years but data sets in which effects were detected were not consistent among years (Table 3). As the use of a linear combination of sine and cosine functions automatically adjusts to the correct phase, the results are reported in Table 3 without time lags. The results of the cross-correlations (Table 2) and visual inspection of the fit of model (not shown) to the observed data series indicated time lags between maximum supply and maximum tidal range of -2 to $-15 \mathrm{~d}$. Along-shore wind stress significantly affected megalopal supply in all years and data sets, at time lags between -4 and $0 \mathrm{~d}$, except in 2006 and 2009, when significant results were obtained only in some of the data sets (Table 3). These time lags are within the expected response times of the coastal ocean to along-shore winds in terms of alongand across-shore circulation. However, the sign of the

Table 2. Time lags (d) and cross-correlations ( $r$ in parentheses) between Carcinus maenas megalopal supply (Meg) and tidal range (TR), chlorophyll a concentration (chl a), and night flood hours (NF), applied to the complete data series (All) and to the data obtained before (B90) or after (A90) Day 90. Reported values refer to maximum significant $(p<0.05)$ crosscorrelations in each case; nd: no data; ns: not significant

\begin{tabular}{|ccccc|}
\hline \multirow{2}{*}{ Year } & & \multicolumn{3}{c}{ Meg } \\
\cline { 3 - 5 } & & TR & NF & Chl $a$ \\
\hline 2002 & All & nd & nd & nd \\
& B90 & nd & nd & nd \\
& A90 & $-15(0.261)$ & $+2(0.232)$ & $-5(0.227)$ \\
2006 & All & ns & $+1(0.232)$ & ns \\
& B90 & ns & $-2(0.532)$ & $-12(0.622)$ \\
& A90 & $-15(0.272)$ & $+1(0.247)$ & ns \\
2007 & All & ns & ns & $-14(0.308)$ \\
& B90 & $-2(0.491)$ & $n s$ & $-5(0.790)$ \\
& A90 & ns & ns & $-14(0.350)$ \\
2008 & All & ns & ns & ns \\
& B90 & ns & ns & $-11(0.447)$ \\
& A90 & ns & ns & $-7(0.240)$ \\
2009 & All & ns & ns & ns \\
& B90 & ns & ns & $0(0.761)$ \\
& A90 & ns & ns & $-14(0.199)$ \\
& & & & \\
\hline
\end{tabular}




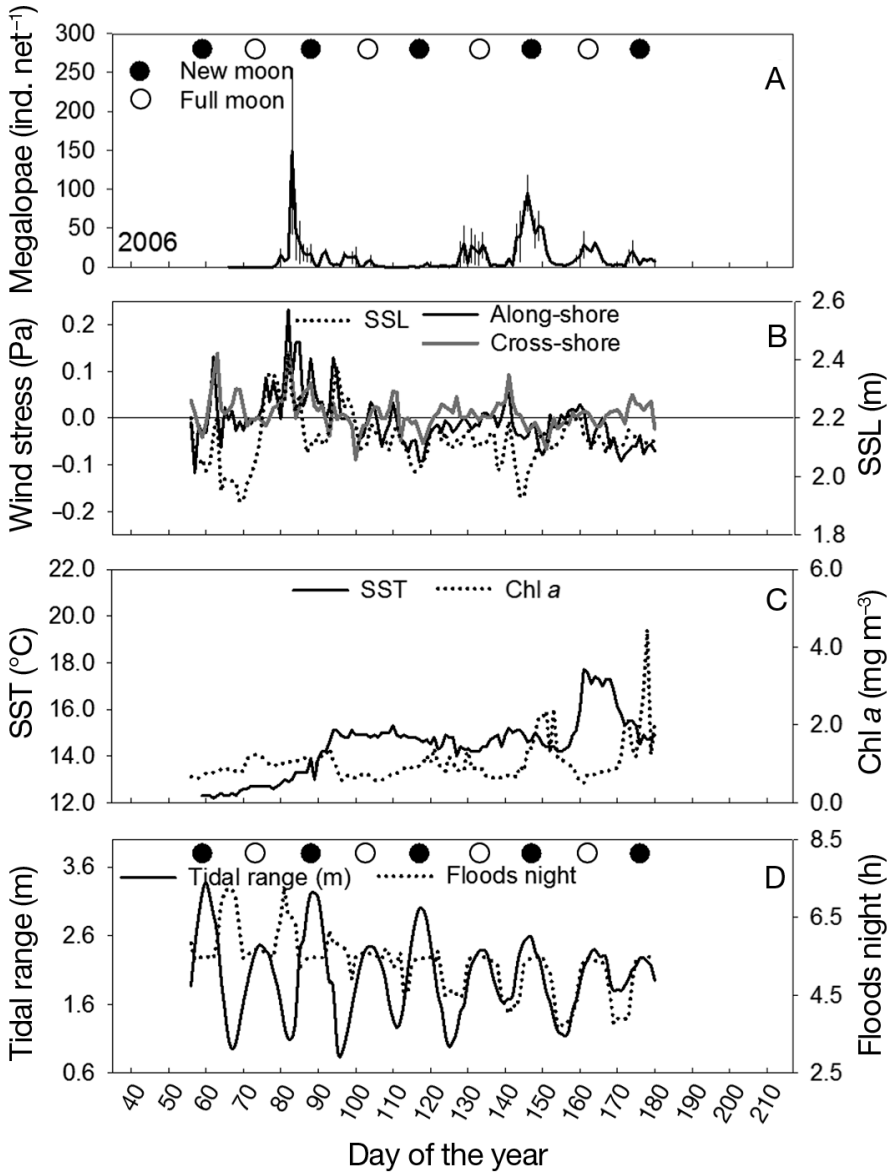

Fig. 3. Time series at Ria de Aveiro for year 2006. See Fig. 2 for details
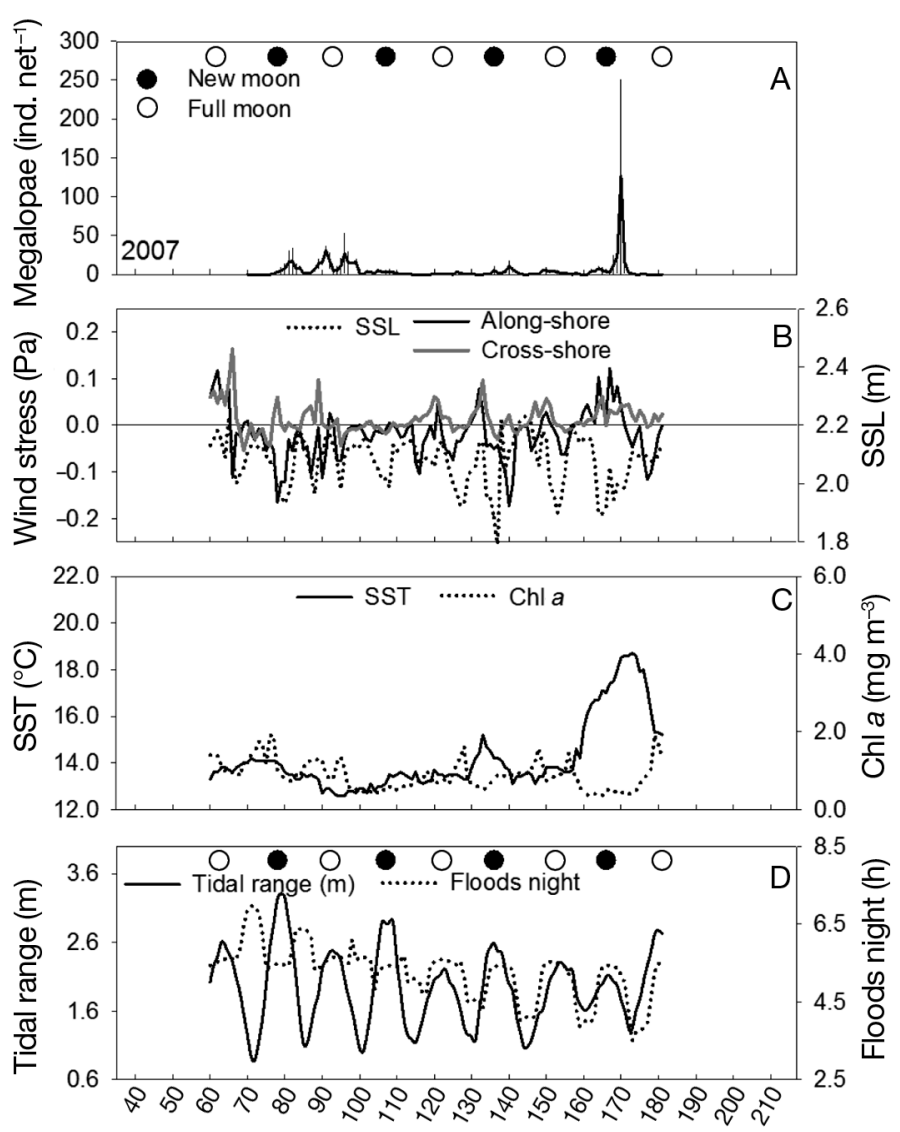

Day of the year

Fig. 4. Time series at Ria de Aveiro for year 2007. See Fig. 2 for details

Table 3. Results of periodic regression models of Carcinus maenas megalopae supply on sine and cosine functions describing the semilunar cycle of tidal range, alongshore wind stress (WS) and chlorophyll a concentration (chl a), applied to the complete data series (All) and to the data obtained before (B90) or after (A90) Day 90. Format of data is lag (regression coefficient, probability level). Lags for sine and cosine are not reported because they are always equal to zero. $r^{* 2}$ is the modified determination coefficient

\begin{tabular}{|c|c|c|c|c|c|c|}
\hline Year & & Sine & Cosine & WS & Chl a & $r^{* 2}$ \\
\hline 2002 & $\begin{array}{l}\text { All } \\
\text { B90 } \\
\text { A90 }\end{array}$ & $\begin{array}{c}\text { nd } \\
\text { nd } \\
(4.765,0.0064)\end{array}$ & $\begin{array}{c}\text { nd } \\
\text { nd } \\
(3.811,0.0321)\end{array}$ & $\begin{array}{c}\text { nd } \\
\text { nd } \\
0(53.905,0.0055)\end{array}$ & $\begin{array}{c}\text { nd } \\
\text { nd } \\
-5(7.721,0.0001)\end{array}$ & $\begin{array}{c}\text { nd } \\
\text { nd } \\
0.641\end{array}$ \\
\hline 2006 & $\begin{array}{l}\text { All } \\
\text { B90 } \\
\text { A90 }\end{array}$ & $\begin{array}{c}\mathrm{ns} \\
(12.637,0.0175) \\
\mathrm{ns}\end{array}$ & $\begin{array}{c}\mathrm{ns} \\
\mathrm{ns} \\
(8.656,0.0075)\end{array}$ & $\begin{array}{c}-1(99.671,0.0140) \\
-1(316.720,0.0001) \\
n s\end{array}$ & $\begin{array}{l}\text { ns } \\
\text { ns } \\
\text { ns }\end{array}$ & $\begin{array}{l}0.412 \\
0.618 \\
0.704\end{array}$ \\
\hline 2007 & $\begin{array}{l}\text { All } \\
\text { B90 } \\
\text { A90 }\end{array}$ & $\begin{array}{c}(-5.041,0.0191) \\
\text { ns } \\
\text { ns }\end{array}$ & $\begin{array}{l}\text { ns } \\
\text { ns } \\
\text { ns }\end{array}$ & $\begin{array}{l}-3(59.513,0.0314) \\
-2(-90.870,0.0006) \\
-3(89.442,0.0053)\end{array}$ & $\begin{array}{c}\mathrm{ns} \\
-3(-10.627,0.0032) \\
\mathrm{ns}\end{array}$ & $\begin{array}{l}0.198 \\
0.733 \\
0.256\end{array}$ \\
\hline 2008 & $\begin{array}{l}\text { All } \\
\text { B90 } \\
\text { A90 }\end{array}$ & $\begin{array}{c}\text { ns } \\
\text { ns } \\
(-3.302,0.0286)\end{array}$ & $\begin{array}{l}\text { ns } \\
\text { ns } \\
\text { ns }\end{array}$ & $\begin{array}{l}-4(45.007,0.0328) \\
-3(-54.211,0.0100) \\
-4(108.467,0.0000)\end{array}$ & $\begin{array}{c}\mathrm{ns} \\
-7(-6.752,0.0234) \\
-7(7.982,0.0270)\end{array}$ & $\begin{array}{l}0.228 \\
0.640 \\
0.288\end{array}$ \\
\hline 2009 & $\begin{array}{l}\text { All } \\
\text { B90 } \\
\text { A90 }\end{array}$ & $\begin{array}{c}\mathrm{ns} \\
(0.492,0.0001) \\
\mathrm{ns}\end{array}$ & $\begin{array}{c}\mathrm{ns} \\
(1.000,0.0001) \\
\mathrm{ns}\end{array}$ & $\begin{array}{c}\mathrm{ns} \\
-1(-19.648,0.0001) \\
\mathrm{ns}\end{array}$ & $\begin{array}{c}\mathrm{ns} \\
0(1.478,0.0001) \\
\text { ns }\end{array}$ & $\begin{array}{c}\mathrm{ns} \\
0.937 \\
\mathrm{~ns}\end{array}$ \\
\hline
\end{tabular}



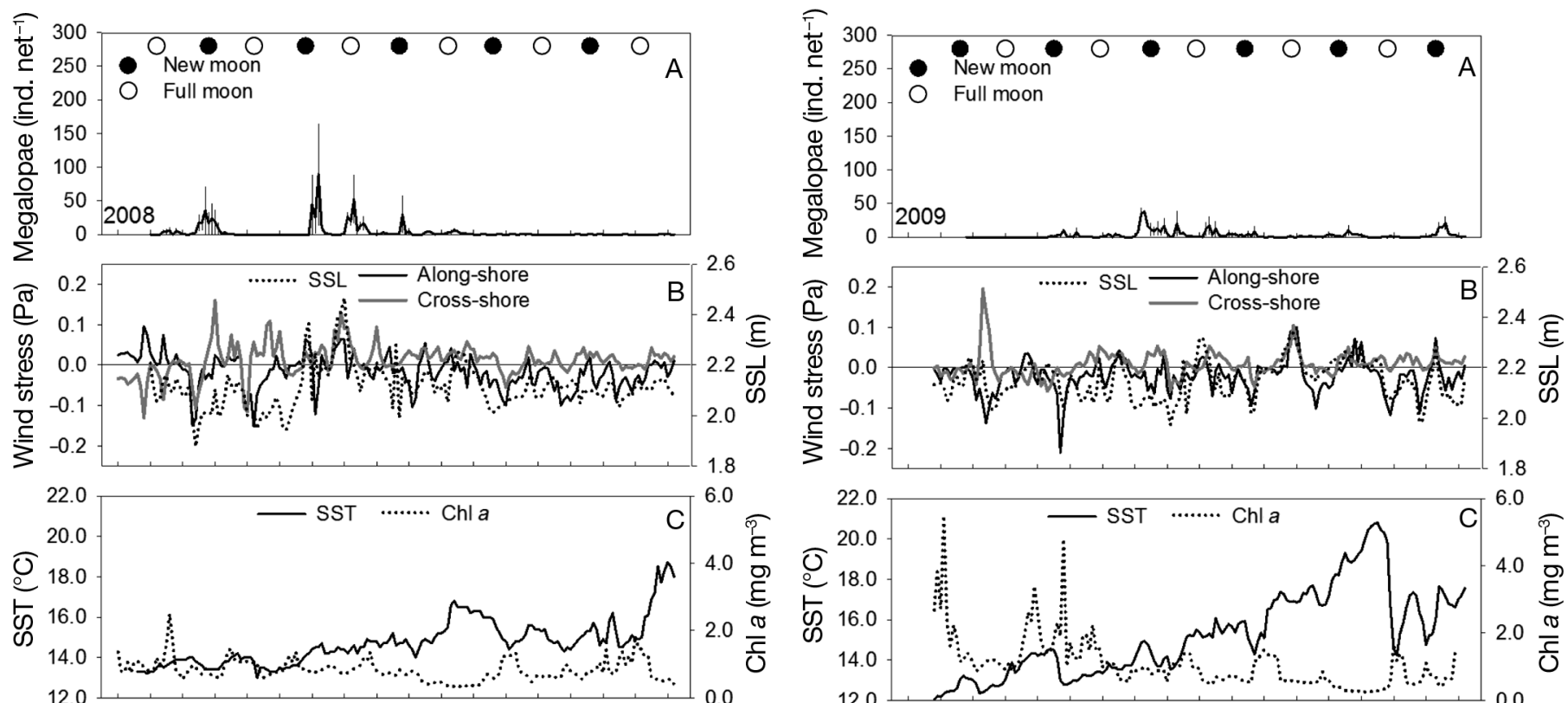

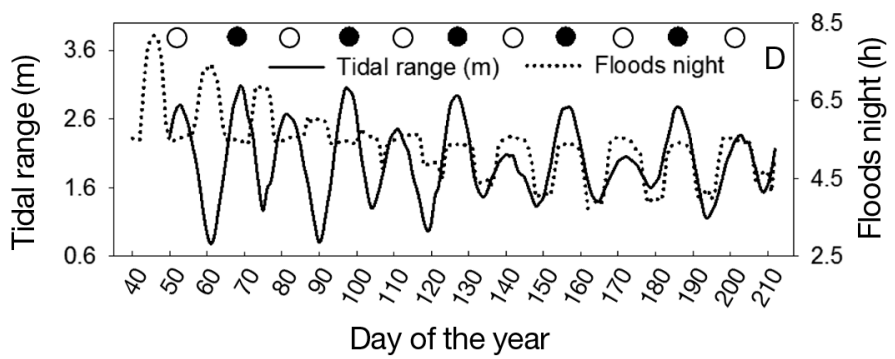

Fig. 5. Time series at Ria de Aveiro for year 2008. See Fig. 2 for details

regression coefficient was not consistent among years and data sets. When a significant effect was found in the complete data sets (2006, 2007 and 2008) the sign was always positive, meaning that southwesterly, downwelling-favourable winds promoted an increase in megalopal supply. The coefficient was also positive in the 3 cases where a significant effect was detected in the data collected after Day 90 (2002, 2007 and 2008). In the data collected before Day 90, the coefficient was positive in 1 (2006) but negative in the other cases (2007, 2008 and 2009), indicating augmented supply with northerly, upwelling-favourable winds. Chl a was related with supply at time lags ranging from -7 to $0 \mathrm{~d}$ in several cases. As with wind stress, the sign of the effect was not consistent, indicating positive as well as negative effects of chl a on megalopal supply. Number of flood hours during darkness was never significantly related with megalopal supply. The modified coefficient of determination $r^{* 2}$ ranged from 0.198 to 0.937 . Usually the split of the time series resulted in better fits of the models, indicated by consistent increases in the $r^{* 2}$ statistic relative to the complete data sets in all years.

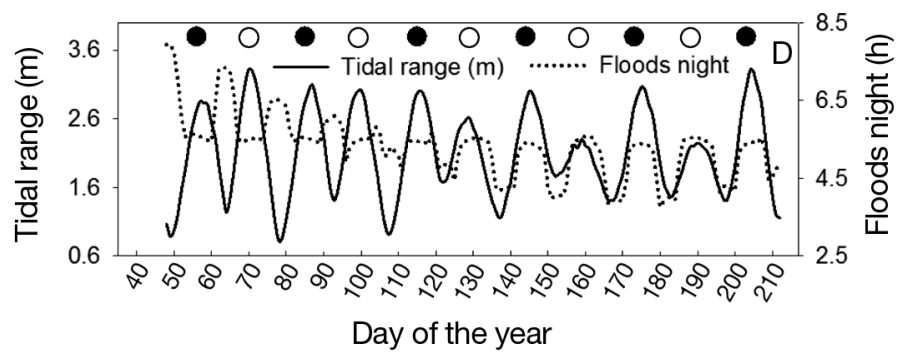

Fig. 6. Time series at Ria de Aveiro for year 2009. See Fig. 2 for details

\section{DISCUSSION}

Supply of Carcinus maenas megalopae to the Ria de Aveiro over 5 separate years during the recruitment season (February to July) was irregular, exhibiting periods of zero or low supply punctuated by episodic peaks. Cross-correlation and multiple regression analysis applied to series of daily observations indicated significant effects of tidal range, along-shore wind stress and chl a concentration on supply, at several time scales within each recruitment season. Peaks of larval supply were often associated with spring tides but effects of wind stress and chl a concentration were not consistent in sign. Moreover, large unexplained variation remained in most cases. Similar investigations have reported that tide- and wind-driven transport are the main mechanisms responsible for supply and settlement of crab megalopae in other coastal systems of the world (van Montfrans et al. 1990, Little \& Epifanio 1991, Moser \& Macintosh 2001, Paula et al. 2001, Miller \& Shanks 2004). However, the results of the present multi-year study show that the response of C. maenas megalopae supply to variation in physical 
variables is more complex and difficult to generalise than previously acknowledged by Queiroga et al. (2006), whose data from larval abundance collected by the passive nets at the Ria de Aveiro in 2002 were included in the present study. Queiroga et al. (2006) sampled only after Year Day 90 and reported an increase in megalopae supply levels at the time of maximum tidal amplitude and after periods of southerly winds or equatorward wind relaxation. In the present study, results obtained with a similar multiple regression approach for the complete data set within each year (2002 series excluded) showed a significant association between larval supply, tidal range and wind stress only in 1 year (2007) and many instances of non-significant associations or of effects of opposite sign in the split data sets.

\section{Tide-driven supply}

Using cross-correlations, we found a fortnightly period of oscillation of megalopae supply at time lags of -15 d (after Day 90 in 2002 and 2006) and -2 d (before Day 90 in 2007). These time lags indicate an immediate response of supply to maximum amplitude tides around new and full moons, as previously identified (Queiroga et al. 2006). The use of sine and cosine functions in the multiple regression increased the detection of significant associations of supply with maximum amplitude tides (in total 8 data sets out of 13 possible). The sampling programme that we used did not allow us to discriminate between the 2 hypotheses usually considered to explain fortnight periods in larval abundance in coastal habitats, viz. the internal wave hypothesis, which is invoked to explain shoreward transport of neustonic larvae over the shelf (Shanks \& Wright 1987, Pineda 1999), or the flood tide hypothesis, which pertains to the immediate behavioural response of crab megalopae to changes in salinity or hydrostatic pressure during flood (DeVries et al. 1994, Tankersley et al. 1995, Welch \& Forward 2001). However, because of the very short delays between maximum tidal range and maximum supply, and, because Carcinus maenas megalopae are not fully neustonic organisms (dos Santos et al. 2008), we would favour the second hypothesis, which implies that the megalopae are already close to shore and are influenced by the tidal current.

\section{Number of flood hours occurring at night}

Most studies describing colonisation of estuaries by crab megalopae refer to transport mainly during nocturnal flood tides (e.g. Christy \& Morgan 1998,
Queiroga 1998). The co-occurrence of darkness and flood in western Iberia is maximised during spring tides after Day 90 (Queiroga \& Blanton 2004), and indeed, during the studied period, the correlation between tidal range and the number of flood hours occurring at night was maximised during the spring and summer months (not shown). Positive crosscorrelations between night flood hours and larval supply were significant only in 2 years (2002 and 2006) for the period after Day 90, at time lags of +1 and $+2 \mathrm{~d}$. However, if megalopae are also responding to the length of flood tides under the cover of darkness during supply to, and migration up, estuaries (Christy \& Morgan 1998, Queiroga 1998), then we would expect a reinforcement of a semilunar oscillation in supply during spring and summer. A simple visual inspection of the supply data series (Figs. 2A to $6 \mathrm{~A}$ ) indicates that repeated peaks at periods of 14 to $15 \mathrm{~d}$, which were also identified by the cross-correlation and multiple regression analyses, only occurred during spring and summer (of 2002, 2006 and 2008).

\section{Wind-driven supply}

Overall, the coastal ocean responded quickly to wind-driven circulation as evidenced by the significant cross-correlations of along-shore wind stress with SST and SSL, which dropped or rose following periods of northwesterly or southwesterly winds, respectively. The sign of the effects of wind stress on SST and SSL and the response time detected are within the predictions of upwelling theory and of previous observations (Wooster et al. 1976, Jorge da Silva 1992).

We found some larval events that were clearly predicted by strong southwesterly winds, which caused an immediate increase in SSL produced by coastal convergent currents. The clearest examples were the supply peaks that took place from Days 82 to 88 in 2006 and from Days 167 to 171 in 2007, which yielded ca. 150 and 125 megalopae per net, respectively, in a single day. Significant effects of wind stress on supply were always positive for the complete data set and for observations made after Day 90, in accordance with previous observations (Queiroga et al. 2006), but negative effects were usually detected before Day 90. Interpretation of these results requires some speculation in light of the current knowledge about larval behaviour and direction of transport over the shelf. Carcinus maenas larvae are known to perform extensive diel vertical migrations in shelf waters, being more abundant close to the surface during the night (dos Santos et al. 2008). The results of a modelling study (Marta-Almeida et al. 2006) showed that this behaviour should promote retention of larvae in the inner shelf during upwelling, caused by the extended period of time spent by the larvae in the shore- 
ward undercurrent. Retention in the inner shelf should favour increased recruitment, but the present data do not support this simple interpretation. If diel vertical migration directly affects supply to estuaries, then the negative effect of wind stress on supply detected in winter would be explained, but a change in migration behaviour from nocturnal migration in winter to reverse migration during spring and summer would have to be assumed. An alternative explanation is that the alongshore component of ocean circulation is driving most of the variability in supply. Results from a different experiment using the same numerical model (Peliz et al. 2007) predicted a dramatic northward transport driven by downwelling-favourable winds when compared with the net southward transport during upwellingfavourable winds of similar magnitude. Unpublished observations (J. Dubert pers. comm.) indicate that the wind events of the end of March 2006 and end of June 2007 could have caused a northward flow over the inner shelf of up to $35 \mathrm{~km} \mathrm{~d}^{-1}$. Given the time lags identified ( -1 to $-4 \mathrm{~d})$, this interpretation would account for the strong supply peaks, provided that pools of competent megalopae are available in the coastal ocean a few tens to $100 \mathrm{~km}$ to the south of the Ria de Aveiro. Since estuaries and rias are distributed along the western Iberian coast at 20 to $60 \mathrm{~km}$ intervals and the planktonic larval duration of C. maenas is around 4 to $6 \mathrm{wk}$, this interpretation seems more plausible than invoking a change in larval behaviour with season, which has never been documented (Queiroga \& Blanton 2004). Variation of supply strength with along-shore currents at intra-year time scales would also be compatible with the negative effects of along-shore wind stress detected in winter. The predominance of southerly winds during winter alternating with northerly winds at periods of $<9 \mathrm{~d}$ on the western Iberian coast (Fiúza et al. 1982) could result in transient pools of megalopae to the north of the Ria, which could be transported southward and recruited to the Ria with northerly wind events.

\section{Chl a concentration}

Upwelling conditions deliver nutrient-rich waters, promoting high levels of phytoplankton production and influencing the variability of chl a concentration along the Portuguese west coast (Oliveira et al. 2009). The multiple regression analysis showed variable relationships between chl a concentration and larval supply levels, with lags of 0 to $-7 \mathrm{~d}$ and negative as well as positive effects. In general, we would expect positive effects of chl a concentration on supply, as an indirect result of greater primary and secondary production that would enhance survival; however, negative effects were also observed. Oliveira et al. (2009) provide evidence that shows patchy distribution of chl $a$ and an asymmetry with surface temperature caused by northerly wind forcing. This complex response of the surface ocean causes temporal and spatial variability that contributes to increased complexity in the interpretation of larval supply levels.

\section{Other possible causes of variability}

As with eastern boundary currents in general, the 2-mode circulation model over the Iberian shelf (reviewed in Relvas et al. 2007), with a poleward current during winter and an equatorward current during summer, is a simplification. During winter, the Iberian Poleward Current (IPC, Peliz et al. 2005) interacts with the Western Iberia Buoyant Plume (WIBP, Peliz et al. 2002) and causes eddy shedding and the occurrence of transient low salinity lenses, fronts and retention zones that may accumulate and transport larvae (Santos et al. 2004). Moreover, intermittent upwelling events occur that increase the complexity of the circulation. During summer, the influence of the WIBP is reduced, but the response of the coastal ocean to upwelling winds is asymmetrical in terms of along-shore and vertical components of circulation, and eddy formation still occurs as a result of the cross-shelf displacement of the IPC with wind events of variable intensity and duration. These mechanisms may be at the base of the complex relationships between ocean circulation and supply events that we detected in the present study, and that are characteristic features of recruitment patterns in many marine populations (Jones \& Epifanio 1995, van Montfrans et al. 1995, Roughgarden \& Smith 1996, Wing et al. 2003, Shanks 2006, Giménez \& Dick 2007, Siegel et al. 2008). The idiosyncratic nature of many of the supply events may also be connected with spatial and temporal differences in larval production, as well as with the length of our study. Highest densities of ovigerous females of Carcinus maenas are found from January to June along the Portuguese coast, with smaller densities in July and August (Queiroga 1995), and maximum densities of early juveniles have been observed from May to July in the Ria de Aveiro (Queiroga 1993). The time series we collected cover most of the species' larval season in all years except 2002. However, seasonality of reproduction implies that the period before Day 90 corresponds to a shorter series than the subsequent period (see Table 1), with possible consequences for our detection of the significance and magnitude of the effects between seasons. Additionally, the long periods with very low or zero supply detected in some years suggest that availability of competent megalopae off the Ria de Aveiro may be very low for extended periods. The topography and geometry of the estuarine mouth should not affect the volume of exchange and larval ingress since the inlet is artificially 
secured by jetties that provide a consistent geometry, and regular dredging for navigation maintains a constant entrance channel. Therefore, the long periods of very low supply are possibly caused by temporal and spatial variations in larval hatching interacting with the subsequent larval advection.

Finally, we would like to note what appears to be a regime shift in Carcinus maenas megalopal supply to the Ria de Aveiro, indicated by better fits of the regression models to the split data series relative to the complete data series (e.g. $r^{* 2}$ in 2006: 0.618 B90 and 0.704 A90 against 0.412 for the complete data series). This regime shift seems to be connected with the cooccurrence of darkness and flood with spring tides between the spring and autumn equinoxes, but could also be associated with the spring transition from a predominantly downwelling to a predominantly upwelling regime that occurs in March to April in the west Iberian margin (Huthnance et al. 2002).

Acknowledgements. We are grateful to all the people who helped with larval collections: B. Silva, F. Pinho, I. Oprea, P. Pochelon, P. Moreira, S. Vilar, S. Waap, S. Pereira, S. Vieira, S. Oliveira and U. Unnikrishnan. We also thank the Administração do Porto de Aveiro who kindly provided access to the sample location, S. Miller for English editing, and 4 anonymous reviewers for their suggestions on improving the manuscript. The Fundação para a Ciência e a Tecnologia (FCT) provided a PhD grant to C.P.D. (SFRH/BD/21593/2005). This work is part of the 'Connect-Connectivity of marine populations assessed with genetic and numerical modelling tools' research project, also funded by the FCT (No. PTDC/BIABDE/65425/2006) under the European Regional Development Fund.

\section{LITERATURE CITED}

Alexander SE, Roughgarden J (1996) Larval transport and population dynamics of intertidal barnacles: a coupled benthic/oceanic model. Ecol Monogr 66:259-275

Almeida MJ, Queiroga H (2003) Physical forcing of onshore transport of crab megalopae in the northern Portuguese upwelling system. Estuar Coast Shelf Sci 57:1091-1102

> Alpuim T, El-Shaarawi A (2008) On the efficiency of regression analysis with AR(p) errors. J Appl Stat 35:717-737

> Byers JE, Pringle JM (2006) Going against the flow: retention, range limits and invasions in advective environments. Mar Ecol Prog Ser 313:27-41

Chatfield C (1996) The analysis of time series data: an introduction, 5th edn. Chapman \& Hall, London

> Christy JH, Morgan SG (1998) Estuarine immigration by crab postlarvae: mechanisms, reliability and adaptive significance. Mar Ecol Prog Ser 174:51-65

> Connolly SR, Menge BA, Roughgarden J (2001) A latitudinal gradient in recruitment of intertidal invertebrates in the northeast Pacific Ocean. Ecology 82:1799-1813

> Cowen RK, Sponaugle S (2009) Larval dispersal and marine population connectivity. Annu Rev Mar Sci 1:443-466

> Cullen JJ (1982) The deep chlorophyll maximum: comparing vertical profiles of chlorophyll a. Can J Fish Aquat Sci 39: 791-803

DeVries MC, Tankersley RA, Forward RB, Kirbysmith WW,
Luettich RA (1994) Abundance of estuarine crab larvae is associated with tidal hydrologic variables. Mar Biol 118: $403-413$

dos Santos A, Santos AMP, Conway DVP, Bartilotti C, Lourenço P, Queiroga H (2008) Diel vertical migration of decapod larvae in the Portuguese coastal upwelling ecosystem: implications for offshore transport. Mar Ecol Prog Ser 359:171-183

- Factor JR, Dexter BL (1993) Suspension feeding in larval crabs (Carcinus maenas). J Mar Biol Assoc UK 73:207-211

> Farrell TM, Bracher D, Roughgarden J (1991) Cross-shelf transport causes recruitment to intertidal populations in central California. Limnol Oceanogr 36:279-288

Fiúza A, Macedo M, Guerreiro M (1982) Climatological space and time variation on the Portuguese coastal upwelling. Oceanol Acta 5:31-40

Franks PJ (1992) Phytoplankton blooms at fronts: patterns, scales, and physical forcing mechanisms. Rev Aquat Sci 6: 121-137

Gaines S, Roughgarden J (1985) Larval settlement rate: a leading determinant of structure in an ecological community of the marine intertidal zone. Proc Natl Acad Sci USA 82:3707-3711

Giménez L, Dick S (2007) Settlement of shore crab Carcinus maenas on a mesotidal open habitat as a function of transport mechanisms. Mar Ecol Prog Ser 338:159-168

Goodrich DM, van Montfrans J, Orth RJ (1989) Blue crab megalopal influx to Chesapeake Bay: evidence for a winddriven mechanism. Estuar Coast Shelf Sci 29:247-260

Harms J, Meyer-Harms B, Dawirs RR, Anger K (1994) Growth and physiology of Carcinus maenas (Decapoda, Portunidae) larvae in the field and in laboratory experiments. Mar Ecol Prog Ser 108:107-118

- Huthnance JM, Van Aken HM, White M, Barton ED and others (2002) Ocean margin exchange-water flux estimates. J Mar Syst 32:107-137

> Jones MB, Epifanio CE (1995) Settlement of brachyuran megalopae in Delaware Bay: an analysis of time series data. Mar Ecol Prog Ser 125:67-76

Jorge da Silva A (1992) Dependence of upwelling related circulation on wind forcing and stratification over the Portuguese northern shelf. ICES CM C:17

> Kalnay E, Kanamitsu M, Kistler R, Collins W and others (1996) The NCEP/NCAR 40-year reanalysis project. Bull Am Meteorol Soc 77:437-471

Little KT, Epifanio CE (1991) Mechanism for the re-invasion of an estuary by two species of brachyuran megalopae. Mar Ecol Prog Ser 68:235-242

> Mace AJ, Morgan SG (2006) Biological and physical coupling in the lee of a small headland: contrasting transport mechanisms for crab larvae in an upwelling region. Mar Ecol Prog Ser 324:185-196

Marta-Almeida M, Dubert J (2006) The structure of tides in the Western Iberian region. Cont Shelf Res 26:385-400

Marta-Almeida M, Dubert J, Peliz Á, Queiroga H (2006) Influence of vertical migration pattern on retention of crab larvae in a seasonal upwelling system. Mar Ecol Prog Ser 307:1-19

> Meyer-Harms B, Harms J (1993) Detection of phytoplankton pigments by HPLC in Hyas araneus larvae (crustacea, decapoda): comparison of field and laboratory samples. Neth J Sea Res 31:153-161

> Miller JA, Shanks AL (2004) Ocean-estuary coupling in the Oregon upwelling region: abundance and transport of juvenile fish and of crab megalopae. Mar Ecol Prog Ser 271:267-279

> Morgan SG, Fisher JL (2010) Larval behavior regulates nearshore retention and offshore migration in an up- 
welling shadow and along the open coast. Mar Ecol Prog Ser 404:109-126

Moser SM, Macintosh DJ (2001) Diurnal and lunar patterns of larval recruitment of Brachyura into a mangrove estuary system in Ranong Province, Thailand. Mar Biol 138: 827-841

> Oliveira PB, Nolasco R, Dubert J, Moita T, Peliz Á (2009) Surface temperature, chlorophyll and advection patterns during a summer upwelling event off central Portugal. Cont Shelf Res 29:759-774

$>$ Olmi EJ (1994) Vertical migration of blue-crab Callinectes sapidus megalopae: implications for transport in estuaries. Mar Ecol Prog Ser 113:39-54

Paula J, Dray T, Queiroga H (2001) Interaction of offshore and inshore processes controlling settlement of brachyuran megalopae in Saco mangrove creek, Inhaca Island (South Mozambique). Mar Ecol Prog Ser 215:251-260

Peliz Á, Rosa TL, Santos AMP, Pissarra JL (2002) Fronts, jets, and counterflows in the Western Iberian upwelling system. J Mar Syst 35:61-77

Peliz Á, Dubert J, Santos AMP, Oliveira PB, Le Cann B (2005) Winter upper ocean circulation in the Western Iberian Basin-fronts, eddies and poleward flows: an overview. Deep Sea Res I 52:621-646

Peliz A, Marchesiello P, Dubert J, Marta-Almeida M, Roy C, Queiroga H (2007) A study of crab larvae dispersal on the Western Iberian Shelf: physical processes. J Mar Syst 68: 215-238

Pineda J (1991) Predictable upwelling and shoreward transport of planktonic larvae by internal tidal bores. Science 253:548-551

Pineda J (1999) Circulation and larval distribution in internal tidal bore warm fronts. Limnol Oceanogr 44:1400-1414

Poulin E, Palma AT, Leiva G, Narvaez D, Pacheco R, Navarrete SA, Castilla JC (2002) Avoiding offshore transport of competent larvae during upwelling events: the case of the gastropod Concholepas concholepas in Central Chile. Limnol Oceanogr 47:1248-1255

Pringle JM, Wares JP (2007) Going against the flow: maintenance of alongshore variation in allele frequency in a coastal ocean. Mar Ecol Prog Ser 335:69-84

Queiroga H (1993) An analysis of the size structure of Carcinus maenas (L.) in Canal de Mira (Ria de Aveiro, Portual) using the probability paper method. Bios 1:89-106

Queiroga H (1995) Processos de dispersão e recrutamento das larvas do caranguejo Carcinus maenas (L.) na Ria de Aveiro. PhD thesis, Universidade de Aveiro

$>$ Queiroga H (1998) Vertical migration and selective tidal stream transport in the megalopa of the crab Carcinus maenas. Hydrobiologia 375/376:137-149

Queiroga H, Blanton J (2004) Interactions between behaviour and physical forcing in the control of horizontal transport of decapod crustacean larvae. Adv Mar Biol 47:107-214

Queiroga H, Almeida MJ, Alpuim T, Flores AAV and others (2006) Tide and wind control of megalopal supply to estuarine crab populations on the Portuguese west coast. Mar Ecol Prog Ser 307:21-36

Queiroga H, Cruz T, dos Santos A, Dubert J and others (2007) Oceanographic and behavioural processes affecting invertebrate larval dispersal and supply in the western Iberia upwelling ecosystem. Prog Oceanogr 74:174-191

Relvas P, Barton ED, Dubert J, Oliveira PB, Peliz Á, Silva JCB, Santos AMP (2007) Physical oceanography of the western Iberia ecosystem: latest views and challenges. Prog

Editorial responsibility: Steven Morgan,

Bodega Bay, California, USA
Oceanogr 74:149-173

Roegner GC, Armstrong DA, Shanks AL (2007) Wind and tidal influences on larval crab recruitment to an Oregon estuary. Mar Ecol Prog Ser 351:177-188

> Roughgarden J, Smith F (1996) Why fisheries collapse and what to do about it. Proc Natl Acad Sci USA 93: 5078-5083

> Roughgarden J, Gaines S, Possingham H (1988) Recruitment dynamics in complex life cycles. Science 241:1460-1466

> Santos AMP, Peliz A, Dubert J, Oliveira PB, Angélico MM, Ré $P$ (2004) Impact of a winter upwelling event on the distribution and transport of sardine (Sardina pilchardus) eggs and larvae off western Iberia: a retention mechanism. Cont Shelf Res 24:149-165

Shanks A (1983) Surface slicks associated with tidally forced internal waves may transport pelagic larvae of benthic invertebrates and fishes shoreward. Mar Ecol Prog Ser 13: 311-315

Shanks AL (1988) Further support for the hypothesis that internal waves can cause shoreward transport of larval invertebrates and fish. Fish Bull 86:703-714

Shanks AL (2006) Mechanisms of cross-shelf transport of crab megalopae inferred from a time series of daily abundance. Mar Biol 148:1383-1398

Shanks AL, Brink L (2005) Upwelling, downwelling, and cross-shelf transport of bivalve larvae: test of a hypothesis. Mar Ecol Prog Ser 302:1-12

Shanks AL, Wright WG (1987) Internal-wave-mediated shoreward transport of cyprids, megalopae, and gammarids and correlated longshore differences in the settling rate of intertidal barnacles. J Exp Mar Biol Ecol 114:1-13

- Siegel DA, Mitarai S, Costello CJ, Gaines SD, Kendall BE, Warner RR, Winters KB (2008) The stochastic nature of larval connectivity among nearshore marine populations. Proc Natl Acad Sci USA 105:8974-8979

Sokal RR, Rohlf FJ (1995) Biometry, 3rd edn. Freeman, New York, NY

Tankersley RA, McKelvey LM, Forward RB (1995) Responses of estuarine crab megalopae to pressure, salinity and light: implications for flood-tide transport. Mar Biol 122:391-400

van Montfrans J, Peery CA, Orth RJ (1990) Daily, monthly and annual settlement patterns by Callinectes sapidus and Neopanope sayi megalopae on artificial collectors deployed in the York River, Virginia: 1985-1988. Bull Mar Sci 46:214-229

van Montfrans J, Epifanio CE, Knott DM, Lipcius RN and others (1995) Settlement of blue crab postlarvae in Western North Atlantic estuaries. Bull Mar Sci 57:834-854

Wei WS (1990) Time series analysis: univariate and multivariate methods. Addison Wesley, Reading, MA

Welch JM, Forward RB (2001) Flood tide transport of blue crab, Callinectes sapidus, postlarvae: behavioral responses to salinity and turbulence. Mar Biol 139:911-918

Wing SR, Botsford LW, Largier JL, Morgan LE (1995) Spatial structure of relaxation events and crab settlement in the northern California upwelling system. Mar Ecol Prog Ser 128:199-211

Wing SR, Botsford LW, Morgan LE, Diehl JM, Lundquist CJ (2003) Inter-annual variability in larval supply to populations of three invertebrate taxa in the northern California Current. Estuar Coast Shelf Sci 57:859-872

Wooster WS, Bakun A, McLain DR (1976) The seasonal upwelling cycle along the eastern boundary of the North Atlantic. J Mar Res 34:131-141

Submitted: September 1, 2010; Accepted: December 11, 2010 Proofs received from author(s): March 2, 2011 